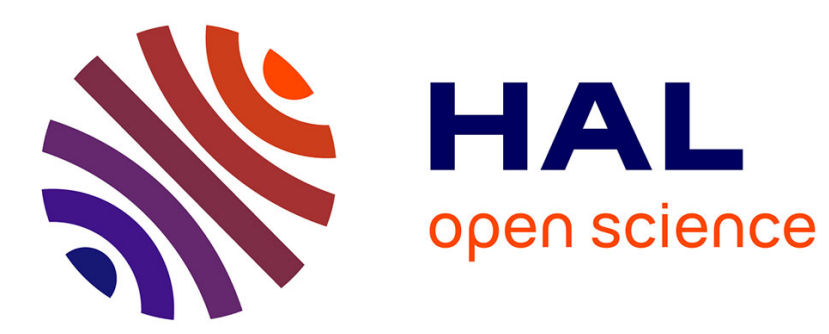

\title{
Impact of COVID-19 pandemic and the lockdown on invasive meningococcal disease
}

Muhamed-Kheir Taha, Ala-Eddine Deghmane

\section{To cite this version:}

Muhamed-Kheir Taha, Ala-Eddine Deghmane. Impact of COVID-19 pandemic and the lockdown on invasive meningococcal disease. BMC Research Notes, 2020, 13 (1), pp.399. 10.1186/s13104-02005241-9 . pasteur-03261549

HAL Id: pasteur-03261549

https://hal-pasteur.archives-ouvertes.fr/pasteur-03261549

Submitted on 15 Jun 2021

HAL is a multi-disciplinary open access archive for the deposit and dissemination of scientific research documents, whether they are published or not. The documents may come from teaching and research institutions in France or abroad, or from public or private research centers.
L'archive ouverte pluridisciplinaire HAL, est destinée au dépôt et à la diffusion de documents scientifiques de niveau recherche, publiés ou non, émanant des établissements d'enseignement et de recherche français ou étrangers, des laboratoires publics ou privés.

\section{(c)(1)}

Distributed under a Creative Commons Attribution| 4.0 International License 


\title{
Impact of COVID-19 pandemic and the lockdown on invasive meningococcal disease
}

\author{
Muhamed-Kheir Taha* (10) and Ala-Eddine Deghmane
}

\begin{abstract}
Objective: Few data are available on the association between SARS-CoV-2 and secondary bacterial infections. Such an association was described for flu and invasive meningococcal disease (IMD). We aimed exploring such a correlation between COVID-19 and IMD as well as the impact of the lockdown on IMD.

Results: We compared IMD cases received at the French National Reference Centre for meningococci and Haemophilus influenzae that are sent as part of the mandatory reporting of IMD. We compared these data during the period 01 January-15 May 2020 to those from the same period in 2018 and 2019. IMD cases that were associated with respiratory presentations significantly increased in 2020 compared to 2018 ( $P=0.029)$ and $2019(P=0.002)$, involved elderly and were due to unusual isolates. However, IMD cases due to hyperinvasive isolates decreased during the lockdown. Enhancing IMD surveillance and anti-meningococcal vaccination in elderly should be addressed.
\end{abstract}

Keywords: Infection, Invasive meningococcal disease, Respiratory presentations, SARS-CoV-2, COVID-19, Typing

\section{Introduction}

Neisseria meningitidis $(\mathrm{Nm})$ is a Gram negative bacterium with airborne inter-human transmission. $\mathrm{Nm}$ is carried asymptomatically in the nasopharynx with $10 \%$ carriers in the general population [1]. However, $\mathrm{Nm}$ is also responsible for invasive meningococcal disease (IMD) that is dominated by septicaemia and meningitis [2]. Nm is highly diverse due to frequent DNA transfer between isolates followed by recombination and allelic exchanges [3]. Genetic typing is crucial for epidemiological surveillance and is performed by DNA sequencing using multilocus sequence typing (MLST) and whole genome sequencing (WGS). The isolates are classified into genetic lineages called clonal complexes (CC) and those that are most frequently associated with IMD are referred to as hyperinvasive $\mathrm{CC}$ but other diverse $\mathrm{CC}$

*Correspondence: mktaha@pasteur.fr Invasive Bacterial Infections Unit and the National Reference Centre for Meningococci and Haemophilus influenzae, Paris, France are more associated with carriage [1]. Risk factors to develop IMD include bacterial virulence factors, host factors such as complement deficiencies and environmental factors such as viral infections where IMD can be associated with respiratory manifestations such as bacteremic pneumonia [2, 4]. The association of viral infections and secondary bacterial infections has been described such as the association between flu and secondary bacterial infections including IMD [5, 6]. During the 1918 pandemic flu, fatality records suggested large impact of secondary bacterial infection [5]. Measures impacting airborne transmitted agents such as social and physical distancing are expected to reduce both flu and Nm transmissions and therefore to reduce the incidence of IMD. Indeed, it has been observed one century ago that bed distancing of 3 feet in military barracks reduced the risk of IMD outbreak among new recruits [7].

The implementation of lockdown to control COVID19 pandemic may therefore interfere with the epidemiology of IMD. Moreover, sepsis was also observed as a 
common complication during COVID-19 [8]. We therefore checked the impact of the lockdown period during the COVID-19 pandemic in France on IMD cases.

\section{Main text}

We screened the database of the French national reference centre for meningococci and Haemophilus influenzae (NRCMHi) for biologically confirmed IMD cases (meningococci detected by culture and/or PCR from a normally sterile site) and compared data for the period between 01 January and 15 May of 2018, 2019 and 2020 using the Chi squared test. Meningococcal isolates are sent to the NRCMHi for full typing (MLST and WGS) as part of the mandatory reporting of IMD [9]. A total of 507 cases of IMD were received at the NRCMHi for the 3 years (202 in 2018, 176 in 2019 and 129 in 2020). The global numbers of cases were decreasing since 2018. The first raison was most likely the introduction of the mandatory vaccination against group $\mathrm{C}(\mathrm{NmC})$ meningococci in January 2018. IMD due to serogroup $C$ decreased from 49 cases in 2018 to 11 cases in $2020(P=0.002$ Chi Square Test) while the changes in the other serogroups was not significant. The number of IMD cases did not significantly differ between 2018, 2019 and 2020 before the period 16 March-15 May (Table 1 and Fig. 1). However, when the analysis focused on the lockdown period (16 March 2020-15 May 2020), the decrease of all IMD cases (regardless the serogroup) from 2018 was significant with only 23 IMD cases during the lockdown period in 2020 versus 2018 and 2019 with 73 IMD and $68(P=0.002$ and 0.001 Chi Square Test) respectively (Table 1 and Fig. 1). Moreover, the decrease during the lockdown, seemed to mainly involve IMD cases due to serogroups $B$ and $C$ and $\mathrm{W}$ but not IMD due to serogroup $\mathrm{Y}$ and other unusual serogroups or non-serogroupeable isolates which did not decrease significantly and which proportions increased during the lockdown 2020 (Table 1 and Fig. 1). A special attention was drawn to IMD cases due to serogroup W as they were continuing to increase in 2020 before the lockdown. The emergence of highly transmissible and hyperinvasive serogroup $\mathrm{W}$ isolates of the clonal complex CC11 was described in France as in other countries in Europe since 2013 [10, 11]. The serogroup W isolates showed a sharp decrease during the lockdown (3 cases in 2020 during the lockdown versus 14 and 21 cases during the corresponding period in 2018 and 2019; $P=0.005$ and $P=0.001$ respectively using Chi Square Test). Moreover, The decrease contrasted with the increasing number of IMD cases due to serogroup W before the lockdown period in 2020 compared to the same period in 2018 and 2019 ( 31 cases before the lockdown in 2020 versus 18 and 20 cases for the corresponding period in 2018 and 2019, $P=0.1$ and $P=0.027$ respectively using Chi Square Test).
The decrease during the lockdown involved mainly the highly transmissible and hyperinvasive isolates belonging to the clonal complex CC11 [11] that almost disappeared.

The MLST typing data were obtained for 468 cases (92\% of all IMD cases of this report; 180 for 2018, 166 for 2019 and 122 for 2020). The distribution of genetic lineages differed mainly during the lockdown period in 2020 compared to the same period in 2018 and 2019 with lower proportion (although not significantly), of hyperinvasive genetic lineages in 2020 during the lockdown period ( $45 \%$ in 2020 versus $68 \%$ and $65 \%$ for the same period in 2018 and 2019 respectively). This proportion did not differ outside the period corresponding to the lockdown for the 3 years (Table 1 and Fig. 1). The genotypes that did not changed in 2020 were CC23 and the isolates belonging to the unassigned clonal complexes (UA). These isolates were frequently of serogroup Y (Additional file 1: Table S1). Indeed, IMD due to serogroup Y is frequently observed in elderly and is associated with flu and respiratory manifestations such as bacteremic pneumonia [4, 12]. Secondary invasive meningococcal infections have been reported to occur 7 to 10 days after flu infections $[4,6]$. Interestingly, sepsis was also observed as a common complication during COVID-19 and occurred at a median of 9.0 days (7.0-13.0) after illness onset although the bacterial aetiology was not explored [8]. We therefore explored whether IMD (detectable meningococci in a normally sterile site) was more frequently detected in association with respiratory presentations since the emergence of SARS CoV-2. We screened the NRCMHi database for IMD cases that were associated with "pneumonia" or "bronchopneumonia" as clinical manifestations. A total of 38 cases were detected: 18 cases (14\%) in 2020 versus, 13 cases $(6 \%)$ and 7 cases $(4 \%)$ in 2018 and $2019(P=0.029$ and $P=0.002$ using Chi Square Test) respectively. The comparison between the year 2020 and 2019 is highly reliable as the seasonal flu peak occurred in both years at week 6 while in the year 2018 the season flu was more extended with a wide peak over the period between week 01 and week 10 [13]. Several of the 2020 IMD cases were preceded by clinically suspected SARSCoV-2 infection (Additional file 1: Table S1). These cases were not reported elsewhere.

Age and sex distributions did not differ significantly during this period for the 3 years for IMD cases without respiratory manifestations (Table 1 ). However, the age distribution differed significantly when respiratory presentations were present compared to cases without respiratory manifestations for each year. Indeed, median ages for IMD cases without respiratory manifestations were 20.7, 21.1 and 20.5 for 2018, 2019 and 2020 respectively (Table 1). These median ages for IMD cases with respiratory manifestations were $74(P<0.001$ Chi Square Test), 


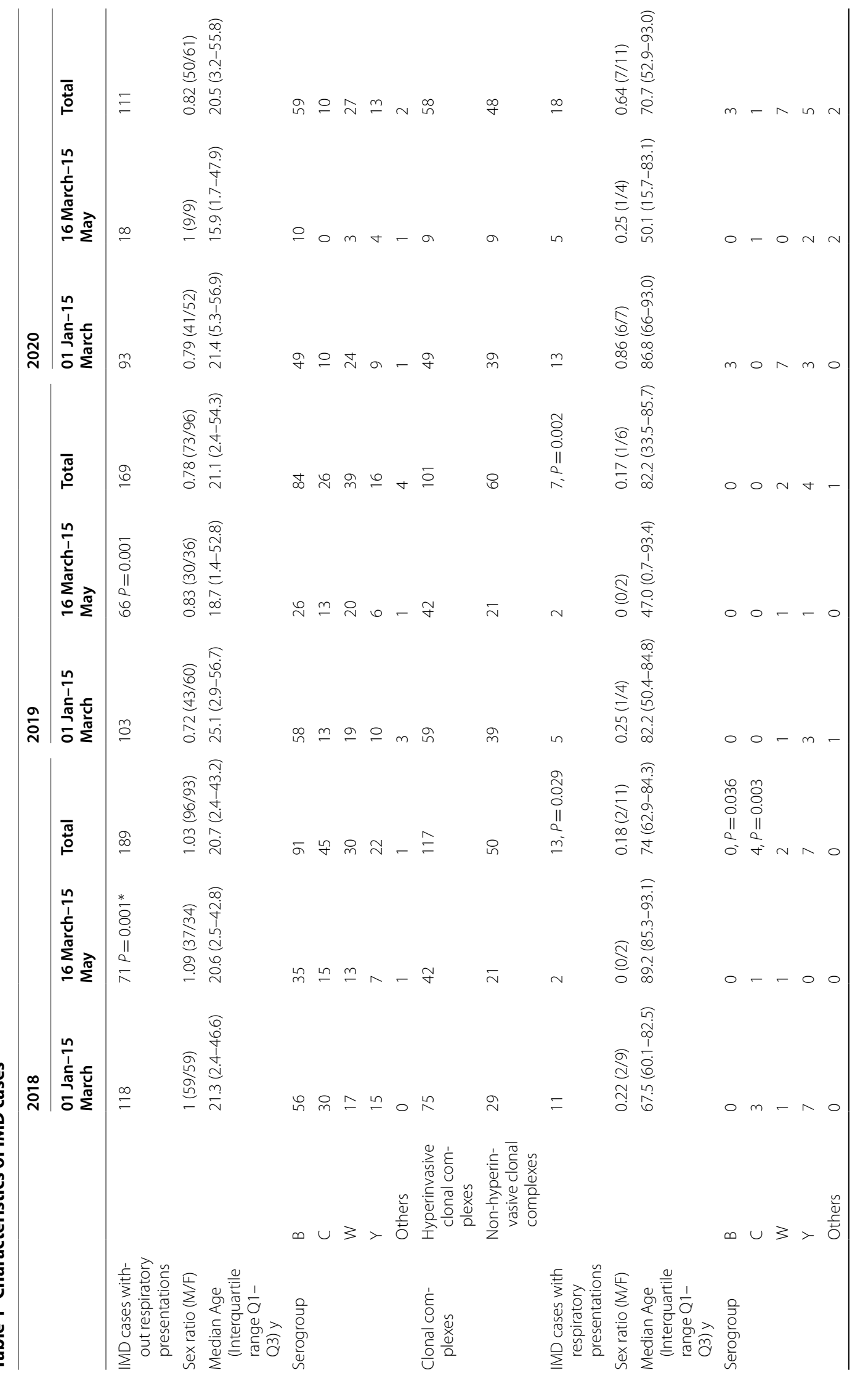




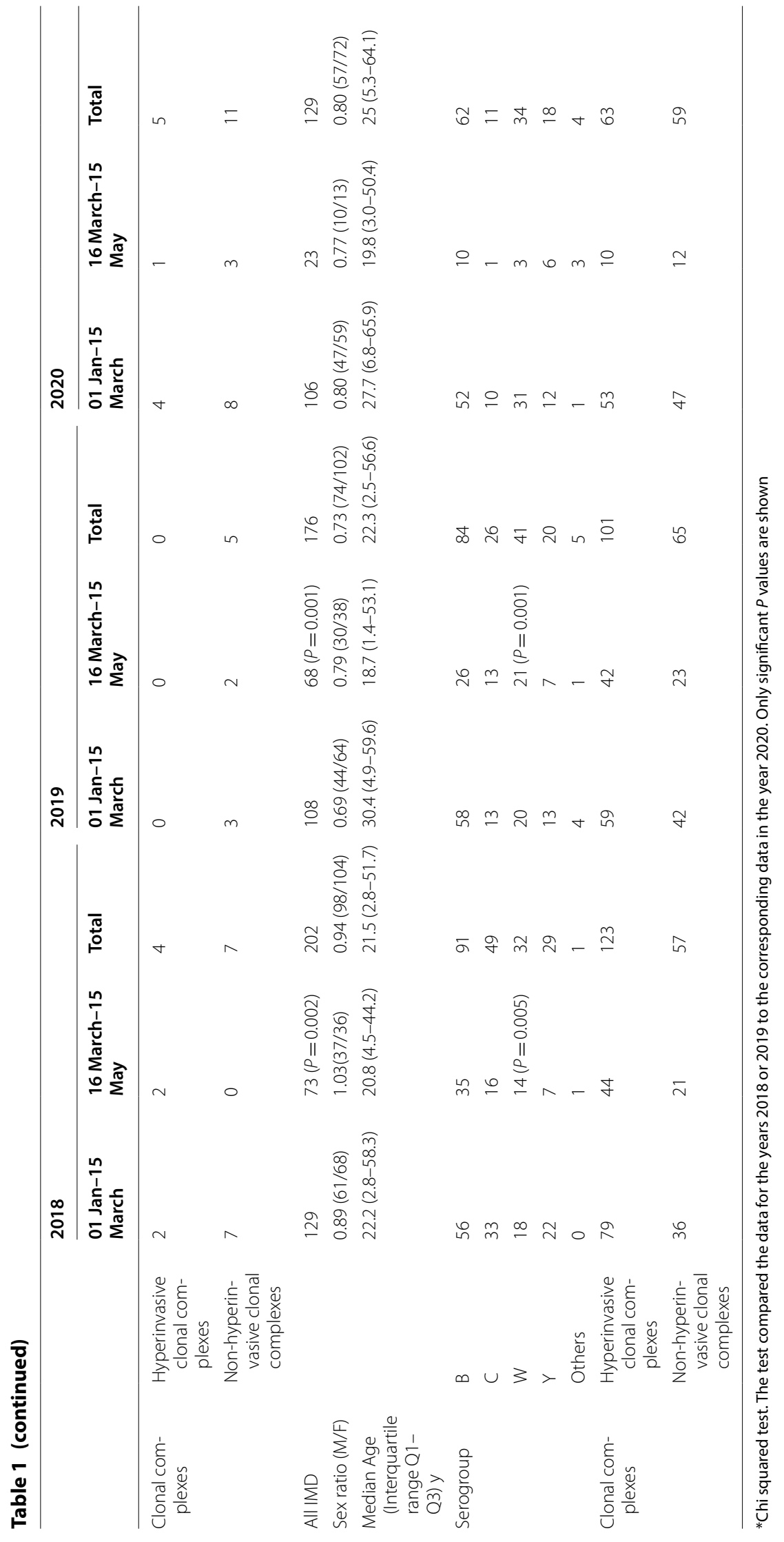



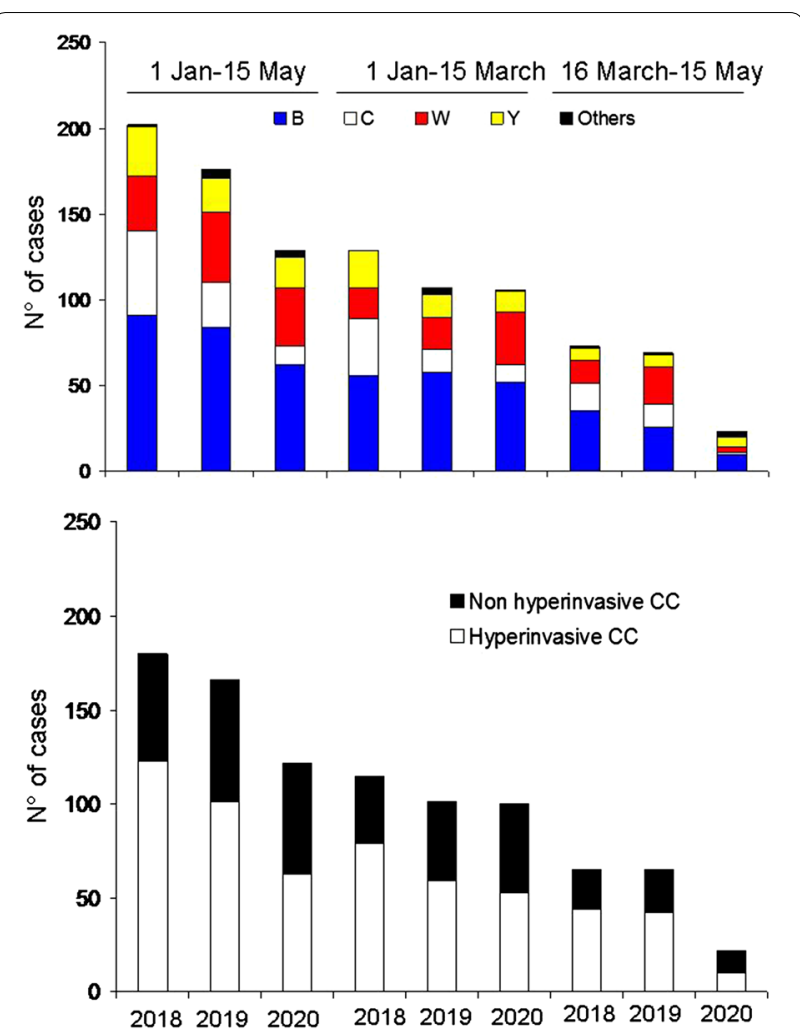

Fig. 1 Distribution of isolates responsible for IMD according to serogroups (above) and genetic lineages (down) during the three periods of 2018-2020 as indicated. Hyperinvasive CC are CC11, CC32, CC41/44 and CC269 [3]

82.2 $(P=0.016$ Chi Square Test $)$ and $70.7(P<0.001$ using Chi Square Test) for the 3 years respectively) (Table 1 ). It is noteworthy that more males were present among cases with respiratory manifestations in 2020 compared to 2018 and 2019 (Table 1). Serogroup distribution also differed for cases with respiratory manifestations compared to cases without respiratory presentations. The proportions of serogroups $\mathrm{W}$ and $\mathrm{Y}$ isolates were significantly higher among IMD cases with respiratory presentations (Table 1) in 3 years underlining the role of these isolates in respiratory forms of IMD $[4,6]$. These isolates (in particular serogroup $\mathrm{W}$ isolates) belonged mainly to non hyperinvasive genetic lineages (Fig. 1 and Additional file 1: Table S1).

The lockdown seems to have reduced inter-human meningococcal transmission that was associated with significantly lower number of "usual" IMD cases compared to the corresponding periods of 2018 and 2019. This decrease involved hyperinvasive but not the nonhyperinvasive isolates further underlying that the former may show higher transmission rates. Moreover, clinical forms with respiratory manifestations seem to increase on the basis of the non-hyperinvasive isolates that may be carried for longer period although of lower virulence. Our data suggest that the increase in these respiratory forms of IMD was concomitant with the COVID-19 pandemic and was mainly observed among elderly and more frequently among males similarly to severe COVID-19 cases [14]. More investigations are required to explore whether these data reveal an enhanced susceptibility to IMD that may be directly linked to the SARS-CoV-2 infections [15]. An additional interference between COVID-19 and IMD may originate from the use of anticomplement drugs that are explored to control COVID19 by lowering complement mediated pro-inflammatory response [16]. These drugs such as anti-complement compounded 5 (C5) are known to increase the risk for IMD [17].

\section{Limitations}

Several of IMD cases with respiratory presentations corresponded to suspected COVID-19. However, no PCR or serological confirmations of COVID-19 were available for all these cases. Moreover, it is important to underline that our data do not support using or not antibiotics in COVID-19 patients as these questions still require more investigations. Finally, our data correspond to a snapshot of the evolution of IMD epidemiology during a short period of time. Long-term surveillance is required. In the meanwhile, our data highlight the need to enhance surveillance of IMD and to consider large anti-meningococcal vaccination and prophylaxis not only in children but also in elderly.

\section{Supplementary information}

Supplementary information accompanies this paper at https://doi. org/10.1186/s13104-020-05241-9.

Additional file 1. Characteristics of isolates and samples reported in this work.

\section{Abbreviations}

COVID-19: Corona virus disease 2019; IMD: Invasive meningococcal disease; MLST: Multilocus sequence typing; NRCMHi: National reference centre for meningococci and Haemophilus influenzae; SRAS-CoV-2: Severe acute respiratory syndrome coronavirus 2; WGS: Whole genome sequencing.

\section{Acknowledgements}

We thank all the staff of the NRCMHi.

\section{Authors' contributions}

Both Authors contributed to extraction and analysis of data. MKT drafted the manuscript and both Authors reviewed and agreed on the manuscript. Both authors read and approved the final manuscript.

\section{Funding}

This work was supported by The Institut Pasteur (024519) and Santé Publique France (024598). 


\section{Availability of data and materials}

Data on all cases and all isolates are provided in the Additional file 1: Table S1.

\section{Ethics approval and consent to participate}

Meningococcal isolates were sent to the National Reference Centres for meningococci and Haemophilus influenzae (NRCMHi) for full typing as part of national laboratory surveillance systems and mandatory reporting for invasive meningococcal disease. The use of materials is performed according to the French public health code (Art L1211-2). https://www.lexbase.fr/texte-deloi/57091269-art-11211-2-code-de-la-sante-publique.

\section{Consent for publication}

Not applicable.

\section{Competing interests}

The authors declare that they have no competing interests.

Received: 19 June 2020 Accepted: 19 Auqust 2020

Published online: 27 August 2020

\section{References}

1. Yazdankhah SP, Kriz P, Tzanakaki G, Kremastinou J, Kalmusova J, Musilek $M$, et al. Distribution of serogroups and genotypes among diseaseassociated and carried isolates of neisseria meningitidis from the Czech Republic, Greece, and Norway. J Clin Microbiol. 2004;42(11):5146-53.

2. Rosenstein NE, Perkins BA, Stephens DS, Popovic T, Hughes JM. Meningococcal disease. N Engl J Med. 2001;344(18):1378-88.

3. Jolley KA, Bray JE, Maiden MCJ. Open-access bacterial population genomics: BIGSdb software, the PubMLST.org website and their applications. Wellcome Open Res. 2018;3:124.

4. Feldman C, Anderson R. Meningococcal pneumonia: a review. Pneumonia (Nathan). 2019;11:3.

5. Brundage JF. Interactions between influenza and bacterial respiratory pathogens: implications for pandemic preparedness. Lancet Infect Dis. 2006;6(5):303-12.

6. Rameix-Welti MA, Zarantonelli ML, Giorgini D, Ruckly C, Marasescu M, van der Werf S, et al. Influenza A virus neuraminidase enhances meningococcal adhesion to epithelial cells through interaction with sialic acid-containing meningococcal capsules. Infect Immun. 2009;77(9):3588-95.
7. Glover JA. "Spacing out" in the prevention of military epidemics of cerebro-spinal fever. Br Med J. 1918;2(3019):509-12.

8. Zhou F, Yu T, Du R, Fan G, Liu Y, Liu Z, et al. Clinical course and risk factors for mortality of adult inpatients with COVID-19 in Wuhan, China: a retrospective cohort study. Lancet. 2020;395(10229):1054-62.

9. Parent du Chatelet I, Deghmane AE, Antona D, Hong E, Fonteneau L, Taha MK, et al. Characteristics and changes in invasive meningococcal disease epidemiology in France, 2006-2015. J Infect. 2017;74(6):564-74.

10. Knol MJ, Hahne SJM, Lucidarme J, Campbell H, de Melker HE, Gray SJ, et al. Temporal associations between national outbreaks of meningococcal serogroup W and C disease in the Netherlands and England: an observational cohort study. Lancet Public Health. 2017;2(10):e473-82.

11. Hong E, Barret AS, Terrade A, Denizon M, Antona D, Aouiti-Trabelsi M, et al. Clonal replacement and expansion among invasive meningococcal isolates of serogroup W in France. J Infect. 2018;76(2):149-58.

12. Sall O, Stenmark B, Glimaker M, Jacobsson S, Molling P, Olcen $\mathrm{P}$, et al. Clinical presentation of invasive disease caused by Neisseria meningitidis serogroup Y in Sweden, 1995 to 2012. Epidemiol Infect. 2017;145(10):2137-43.

13. Campèse $C$, Jung YJ, Lévy-Bruhl D, Savitch Y. Semaine 09. Saint Maurice: Santé Publique France; 2020 04/03/2020.

14. Kragholm K, Andersen MP, Gerds TA, Butt JH, Ostergaard L, Polcwiartek C, et al. Association between male sex and outcomes of Coronavirus Disease 2019 (Covid-19) — a Danish nationwide, register-based study. Clin Infect Dis. 2020. https://doi.org/10.1093/cid/ciaa924/5868546.

15. Rawson TM, Moore LSP, Zhu N, Ranganathan N, Skolimowska K, Gilchrist $M$, et al. Bacterial and fungal co-infection in individuals with coronavirus: a rapid review to support COVID-19 antimicrobial prescribing. Clin Infect Dis. 2020. https://doi.org/10.1093/cid/ciaa530.

16. Cugno M, Meroni PL, Gualtierotti R, Griffini S, Grovetti E, Torri A, et al. Complement activation in patients with Covid-19: a novel therapeutic target. J Allergy Clin Immunol. 2020;146:215-7.

17. Ladhani SN, Campbell H, Lucidarme J, Gray S, Parikh S, Willerton L, et al. Invasive meningococcal disease in patients with complement deficiencies: a case series (2008-2017). BMC Infect Dis. 2019;19(1):522.

\section{Publisher's Note}

Springer Nature remains neutral with regard to jurisdictional claims in published maps and institutional affiliations.
Ready to submit your research? Choose BMC and benefit from:

- fast, convenient online submission

- thorough peer review by experienced researchers in your field

- rapid publication on acceptance

- support for research data, including large and complex data types

- gold Open Access which fosters wider collaboration and increased citations

- maximum visibility for your research: over $100 \mathrm{M}$ website views per year

At $\mathrm{BMC}$, research is always in progress.

Learn more biomedcentral.com/submissions 